\title{
Noise Effects of Generator Sets at Construction Sites
}

\section{Abstract:}

Noise and vibration can be the cause of serious disturbance and inconvenience to anyone exposed to them and in certain circumstances noise and vibration can be a serious hazard to health, causing permanent damage to hearing system. Noise exposure levels of construction workers are difficult to determine due to the day to-day variation in occupation and shift length of each worker and the itinerant and seasonal nature of the job. Nevertheless, it is clear that the construction worker is exposed to very high sound levels for considerable lengths of time.

Different types and sizes of equipment's, machineries and tools are used by construction industries. Diesel Generator for power is a very important one among the equipment used in the construction industries, used in large numbers and as clusters and also located very near to the work area. The noise level produced by these generators is much higher than the permissible limit. But the construction work group took very little effort to avoid or minimize this noise level to permissible level. Many people even though they may not need electricity for their work got in and exposed in this zone of danger. At this site eight generators have been used by various working groups.

This paper assesses the potential noise impacts associated with power generators used in construction activities of the DCT project site and the effective steps to control this noise. A 12-hour noise survey was conducted to establish background noise levels in the project area.

Key Words: Construction workers; noise; power generators; DCT.
Sellappan Elancheliyan

HSE Manager, Eversendai Engineering Qatar WLL,

P.O.Box:35283. Street No.41 New Industrial Area, Doha - Qatar.

Corresponding Author:

Er. Sellappan Elancheliyan Email: elankani@gmail.com

๑ 2013 IJOSH All rights reserved.

DOI: http://dx.doi.org/10.3126/ijosh.v3i2.6145

\section{Introduction}

Noise: "any loud, discordant or disagreeable sound." Noise intensity is measured in decibel units [1,2]. The decibel scale is logarithmic; each 10-decibel increase represents at enfold increase in noise intensity [6]. Human perception of loudness also conforms to a logarithmic scale; a 10-decibel increase is perceived as roughly a doubling of loudness. Thus, 30 decibels is 10 times more intense than 20 decibels and sounds twice as loud; 40 decibels is 100 times more intense than 20 and sounds 4 times as loud; 80 decibels is 1 million times more intense than 20 and sounds 64 times as loud. Noise can cause hearing loss, lack of sleep, irritability, heartburn, indigestion, ulcers, high blood pressure, and possibly heart disease $[3,4]$. Prolonged or frequent exposure to noise tends to make the physiological disturbances chronic. In addition, noise-induced stress creates severe stresses in daily living and contributes to mental illness.

\section{Permissible Noise Exposure Levels}

When the daily noise exposure is composed of two or more periods of noise exposure of different levels [5], their combined effect should be considered, rather than the individual effect of each. The permissible noise exposure levels with time [16] are given in Table I.

Table I Permissible Noise Exposures

\begin{tabular}{|cccccc|}
$\begin{array}{c}\text { Sound } \\
\text { Level } \\
\text { (dBA) }\end{array}$ & $\begin{array}{c}\text { Permitted } \\
\text { duration } \\
\text { per work- } \\
\text { day } \\
\text { (hrs) }\end{array}$ & $\begin{array}{c}\text { Sound } \\
\text { Level } \\
\text { (dBA) }\end{array}$ & $\begin{array}{c}\text { Permitted } \\
\text { duration } \\
\text { per work- } \\
\text { day } \\
\text { (hrs) }\end{array}$ & $\begin{array}{c}\text { Sound } \\
\text { Level } \\
\text { (dBA) }\end{array}$ & $\begin{array}{c}\text { Permitted } \\
\text { duration } \\
\text { per work- } \\
\text { day } \\
\text { (hrs) }\end{array}$ \\
\hline 90 & 8.00 & 99 & 2.30 & 108 & 0.66 \\
\hline 91 & 6.96 & 100 & 2.00 & 109 & 0.56 \\
\hline 93 & 6.06 & 101 & 1.73 & 110 & 0.50 \\
\hline 94 & 5.28 & 102 & 1.52 & 111 & 0.43 \\
\hline 95 & 4.60 & 103 & 1.32 & 112 & 0.38 \\
\hline 96 & 3.48 & 105 & 1.00 & 114 & 0.28 \\
\hline 97 & 3.03 & 106 & 0.86 & 115 & 0.25 \\
\hline 98 & 2.63 & 107 & 0.76 & 116 & 0.21 \\
\hline
\end{tabular}

\section{Equivalent Noise Exposure Factor}

Noise levels are expressed in terms of the energy-equivalent continuous noise level, $L_{e q}$, which normalizes the $L_{e q}$ to an 8 
hour day. This could only be accomplished given a worker's pattern of exposure to noise; workers switch to different jobs/ tools/sites, and their shift length is variable and seasonal. Exposure to different levels for various periods of time shall be computed according to the formula [16].

$L_{e q}=\left(T_{1} / L_{1}\right)+\left(T_{2} / L_{2}\right)+\ldots \ldots \ldots \ldots+\left(T_{n} / L_{n}\right)$

\section{where:}

$\mathrm{L}_{\mathrm{eq}}=$ The equivalent noise exposure factor.

$\mathrm{T}=$ The actual time of noise exposure by person at a constant noise level.

$\mathrm{L} \quad=$ The duration of the permissible noise exposure at the constant level (from Table I).

If the value of $L_{\text {eq }}$ exceeds unity (1) the exposure exceeds permissible levels.

\section{Noise Exposure Levels (Daily $L_{e q}$ ) by Construction Activity}

The DCT project construction will occur over a period of approximately 27 months. In various stages of construction we found a large variety of hand tools and other machinery contributing to a background level which is usually above $85 \mathrm{dBA}$ [7]. Table. 2 provides a list of trade, activity and equipment's that were used during project construction together with associated noise levels [8, 9, 17].

Table II Noise from construction equipment \& Tools

\begin{tabular}{|c|c|c|c|}
\hline Plant/Equipment & $\begin{array}{l}\text { Noise (Leq) } \\
\text { dBA }\end{array}$ & Trade/Tools & $\begin{array}{c}\text { Noise } \\
\left(L_{e q}\right), \text { dBA }\end{array}$ \\
\hline Dozers, Dumpers & $89-103$ & Plumber & 90 \\
\hline $\begin{array}{c}\text { Front end load- } \\
\text { ers }\end{array}$ & $85-91$ & Elevator installer & 96 \\
\hline Excavators & $86-90$ & Rebar worker & 95 \\
\hline Backhoes & $79-89$ & Carpenter & 90 \\
\hline Scrapers & $84-102$ & Concrete form finisher & 93 \\
\hline Mobile Cranes & $97-102$ & Steel stud installer & 96 \\
\hline Manlift & $102-104$ & $\begin{array}{l}\text { Laborers - shovel } \\
\text { hardcore }\end{array}$ & 94 \\
\hline Compressors & $62-92$ & $\begin{array}{l}\text { Laborers - concrete } \\
\text { pour }\end{array}$ & 97 \\
\hline Pavers & $100-102$ & Hoist operator & 100 \\
\hline $\begin{array}{c}\text { Rollers } \\
\text { (compactors) }\end{array}$ & $79-93$ & $\begin{array}{c}\text { Pneumatic chipper/ } \\
\text { chisel }\end{array}$ & 108 \\
\hline Bar Benders & $94-96$ & Compactor & 109 \\
\hline $\begin{array}{l}\text { Pneumatic } \\
\text { breakers }\end{array}$ & $94-111$ & Electric drill & 102 \\
\hline $\begin{array}{l}\text { Hydraulic } \\
\text { breakers }\end{array}$ & $90-100$ & Air track drill & 113 \\
\hline $\begin{array}{l}\text { Pile drivers } \\
\text { (diesel) }\end{array}$ & $82-105$ & Concrete saw & 90 \\
\hline
\end{tabular}

\section{Noise from Power Generators}

Power Generators are essential for use on construction sites where electricity is not supplied. Power generators are used to power electric equipment, welding machines, for general and task lighting.

The workers involved in various works has exposed to various levels of noise by the machinery which they used [10, 18]. Apart from the noise by individual tool, the tools need electricity to work. In construction industries all the required electricity is supplied by the power generators, which also producing huge noise, the workers ultimately are exposed to double effect.

\section{Project Site and Vicinity}

The project extends to larger area whereas this study limited to exhibition hall only. The exhibition hall spread over 140 meter length (East to West) and 90 meter breadth (South to North) gives $12600 \mathrm{~m} 2$ area. The distance between the mega columns was 90 meters and the distance between two grid lines was 18 meters.

Ambient noise measurements were made for two generators at locations G1 \& G2 as shown in Figure.1. This was done to measure the noise effect of individual generator. At the time the noise measurement equipment was set up, the sky was clear, temperatures were in the mid $22^{\circ} \mathrm{C}$, and the wind speed was light and variable. The measurement showed the noise exposure decreased with distance.

Actually the noise environment fluctuated greatly from hour to hour and location to location, depending on work activity within the exhibition hall. So another measurement was made at six locations during a normal working day over a period of 12 day. hours. Similar weather conditions were observed on the day when the measurement was taken down for exhibition hall. The measurement shows that the exhibition hall area is typically noisy throughout a normal working day.

\section{Study Work}

The usual sound sources of an electrical power generator are fan, bearing and sound radiation from the surface. In an electric generator the magnetic field produces the circumferential forces required for the energy transfer. In addition, the field creates radial forces. These forces interact with stator is in contact with the frame, which also is excited. The vibration of the frame accelerates the surrounding air, which is heard as noise [11]. To avoid excessive noise the designer of the generators needs calculate the vibration and noise levels [14]. In this work the noise emission of an electric generator used for power generation operations were studied.

The experimental readings were taken from two standard caterpillar diesel generators, one generator with 365KVA, 1500 rpm and $220 \mathrm{~V}$ output (G1) placed at GL-15, Near to mega column in north side and the other with 500KVA, $1500 \mathrm{rpm}$ and $220 \mathrm{~V}$ output (G2) was located at GL-17, south side mega column No.17and placed 105 meter apart between them. 
Figure 1. Location markings of Generators \& Study points

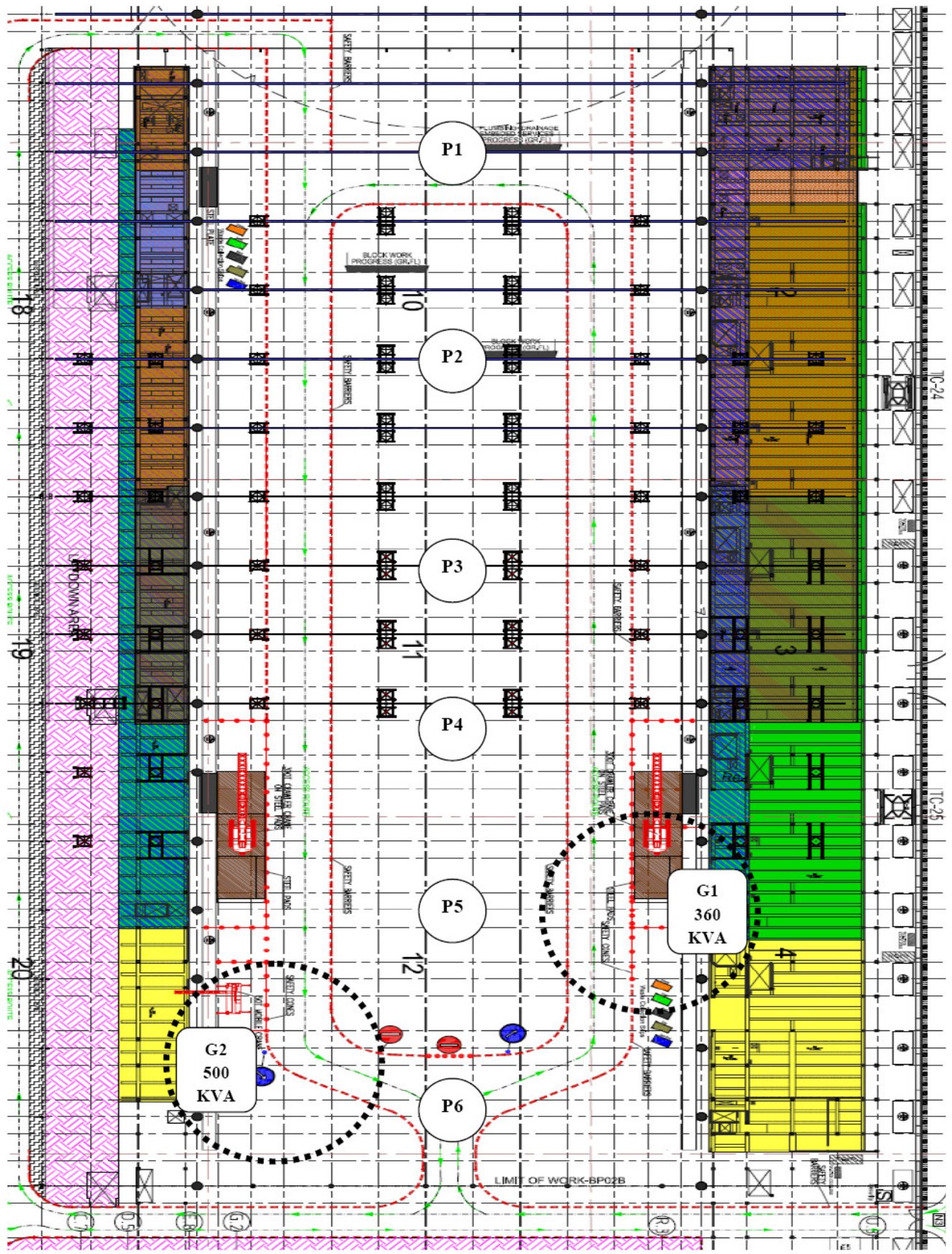

The generators (G1 and $G 2$ ) were not covered or provided with any acoustic shield; hence the entire noise generated will be transmitted to the environment. The exhibition hall was covered with building structure on north and south, covered with decking sheets and concrete on the roof. This makes the entire area to be considered as enclosed space. The noise generated by generators has to absorb and reflected and nothing will be transmitted, which increase the intensity of noise exposure by employees. All other activities in this area were stopped in order to eliminate the noise effect of other work activities. The noise level was observed on 21-02-2012 in a calibrated standard digital sound level meter with RS232 and noted from various distances. Table III presents the summary of noise levels measured at various distances from the source of noise, i.e. generators.
The noise levels from construction activities will vary during the different activity periods, depending upon the activity location and the number and types of equipment being used. Another set of readings were taken exactly the center point (i.e. 45 meter from each column) between the two mega columns of a grid line. Six points were identified or selected to cover the entire exhibition hall area with one point for every three grids. The study locations were marked in figure.3, the points P1 to P6 covered from gridline 3 to grid line 18(i.e. multiple of three). All construction activities in this area were continued in order to account the cumulative noise effect of other work activities. The readings were taken on 25-02-2012 for every one hour for a period of 12 hours (7 am to $7 \mathrm{pm}$ ). The measured values are tabulated in Table IV. 
Table III Noise in dBA from Generator sets

\begin{tabular}{|c|c|c|c|c|c|}
\hline \multirow{3}{*}{$\begin{array}{l}\text { Distance } \\
\text { from the } \\
\text { welding } \\
\text { generator } \\
\text { (m) }\end{array}$} & \multicolumn{2}{|c|}{ Noise Level, dBA } & \multirow{3}{*}{$\begin{array}{l}\text { Distance } \\
\text { from the } \\
\text { welding } \\
\text { generator } \\
\text { (m) }\end{array}$} & \multicolumn{2}{|c|}{ Noise Level, dBA } \\
\hline & $\begin{array}{c}\text { Generator } \\
\text { G1, } \\
360 \mathrm{KVA}\end{array}$ & $\begin{array}{c}\text { Generator } \\
\text { G2, } \\
500 \text { KVA }\end{array}$ & & $\begin{array}{c}\text { Generator } \\
\text { G1, } \\
360 \text { KVA }\end{array}$ & $\begin{array}{c}\text { Generator } \\
\text { G2, } \\
500 \text { KVA }\end{array}$ \\
\hline & $\operatorname{Max}$ & $\operatorname{Max}$ & & & \\
\hline 1.0 & 103.7 & 104.3 & 11.0 & 87.6 & 89.3 \\
\hline 2.0 & 100.0 & 101.3 & 12.0 & 87.4 & 88.3 \\
\hline 3.0 & 97.6 & 99.6 & 13.0 & 87.1 & 87.4 \\
\hline 4.0 & 94.9 & 95.8 & 14.0 & 86.0 & 86.4 \\
\hline 5.0 & 92.5 & 94.3 & 15.0 & 85.1 & 85.6 \\
\hline 6.0 & 91.2 & 93.5 & 16.0 & 84.6 & 85.1 \\
\hline 7.0 & 89.7 & 91.9 & 17.0 & 82.7 & 83.6 \\
\hline 8.0 & 89.4 & 90.6 & 18.0 & 81.3 & 83.2 \\
\hline 9.0 & 88.7 & 90.2 & 19.0 & 80.2 & 82.6 \\
\hline 10.0 & 87.7 & 90.1 & 20.0 & 79.9 & 81.8 \\
\hline
\end{tabular}

Table IV Cumulative Noise effects during working hours, dBA

\begin{tabular}{|ccccccc|}
$\begin{array}{c}\text { Time } \\
\text { (Hrs) }\end{array}$ & $\begin{array}{c}\text { Point, } \\
\text { P1 }\end{array}$ & $\begin{array}{c}\text { Point, } \\
\text { P2 }\end{array}$ & $\begin{array}{c}\text { Point, } \\
\text { P3 }\end{array}$ & $\begin{array}{c}\text { Point, } \\
\text { P4 }\end{array}$ & $\begin{array}{c}\text { Point, } \\
\text { P5 }\end{array}$ & $\begin{array}{c}\text { Point, } \\
\text { P6 }\end{array}$ \\
\hline $7.00 \mathrm{am}$ & 85.4 & 79.3 & 78.6 & 85.7 & 82.4 & 89.1 \\
\hline $8.00 \mathrm{am}$ & 86.5 & 78.9 & 77.8 & 86.8 & 83.5 & 92.5 \\
\hline $9.00 \mathrm{am}$ & 81.3 & 80.6 & 78.0 & 83.2 & 80.5 & 88.1 \\
\hline $10.00 \mathrm{am}$ & 80.5 & 79.7 & 78.9 & 83.5 & 82.6 & 89.5 \\
\hline $11.00 \mathrm{am}$ & 79.8 & 79.4 & 81.8 & 83.0 & 81.1 & 85.2 \\
\hline $12.00 \mathrm{Noon}$ & 77.8 & 78.6 & 80.9 & 82.4 & 80.9 & 85.7 \\
\hline $1.00 \mathrm{pm}$ & 81.4 & 79.6 & 84.1 & 83.2 & 80.1 & 85.9 \\
\hline $2.00 \mathrm{pm}$ & 81.1 & 80.2 & 83.7 & 83.0 & 82.3 & 86.1 \\
\hline $3.00 \mathrm{pm}$ & 80.3 & 78.8 & 83.5 & 82.0 & 80.2 & 86.4 \\
\hline $4.00 \mathrm{pm}$ & 81.5 & 80.0 & 82.9 & 84.4 & 81.5 & 85.8 \\
\hline $5.00 \mathrm{pm}$ & 81.6 & 79.9 & 80.8 & 81.4 & 82.1 & 82.7 \\
\hline $6.00 \mathrm{pm}$ & 80.6 & 79.5 & 80.3 & 82.7 & 81.1 & 82.8 \\
\hline $7.00 \mathrm{pm}$ & 79.1 & 76.2 & 79.5 & 80.1 & 79.8 & 82.5 \\
\hline
\end{tabular}

\section{Result and Discussion}

Based on the noise level observed from the generators, the noise level is higher than the permissible level, at $1.0 \mathrm{~m}$ from the generator; the values noted are $103.7 \mathrm{dBA}$ and $104.4 \mathrm{dBA}$ for $\mathrm{G} 1$ and $\mathrm{G} 2$ respectively. These values decreases with increase in distance and it reaches the permissible level of $90 \mathrm{dBA}$ at $7.0 \mathrm{~m}$ for $\mathrm{G} 1$ and $10.5 \mathrm{~m}$ for $\mathrm{G} 2$ generators. Even though the permissible level is $90 \mathrm{dBA}$; hearing damage begins at a much lower level, about 85 decibels. This value is observed at $15 \mathrm{~m}$ and $16 \mathrm{~m}$ for $\mathrm{G} 1$ and $\mathrm{G} 2$ generators respectively. The effect of distance on noise is given in Figure. 2

Figue.2. Effect of distance on noise level from generators

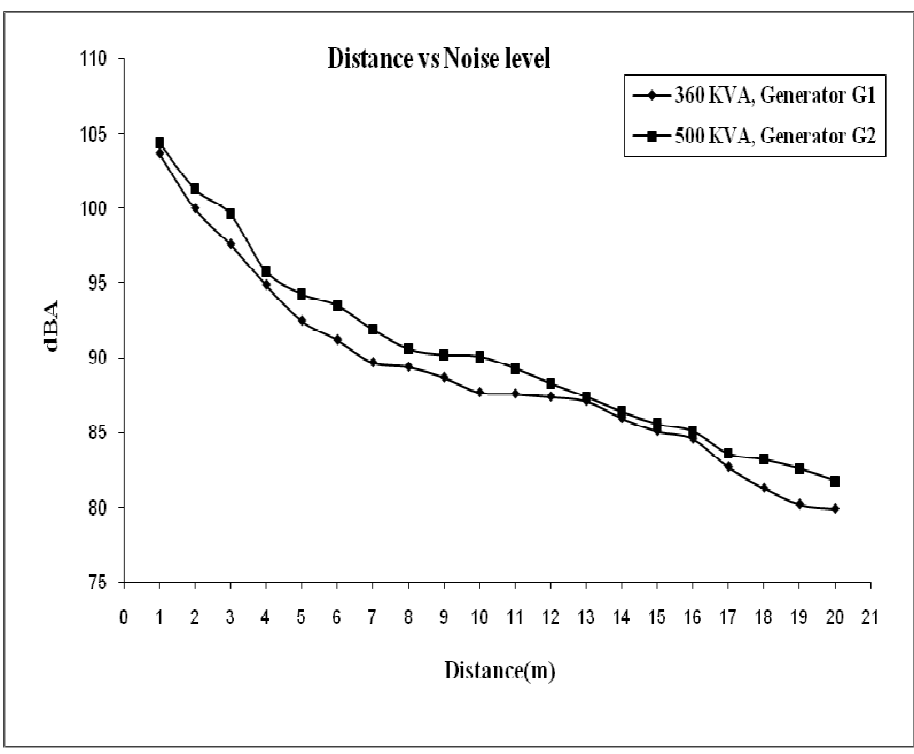

Construction noise would vary throughout the build-out of the Project according to specific activities, location, orientation of the activities, and changing equipment operations. To study the noise effects in the exhibition hall during a normal working day, a total of 78 noise measurements were made and data obtained were analyzed. Figure.3 presents a summary of graphical analysis of noise data. The overall average of noise level observed was $82.05 \mathrm{dBA}$ which exceeds the threshold of 70 $\mathrm{dBA}$. The measured noise levels increased with points nearby the generators. The maximum noise exposure noted was 92.5 $\mathrm{dBA}$ at point P6.

As shown in this graph, the majority of inhabited (community) receptor -related noise levels that would be from P4 to P6. For these locations, construction noise would be expected to be clearly audible during most of the daytime hours, depending on the actual, onsite construction activities. These points of perceptibility are not considered significant, however, based on the temporary nature of the construction phases and the intermittent duration of the worst-case activities. Other locations P2 and P3, would have construction-related noise levels, but below to any other location.

\section{Mitigation Measures}

The cumulative noise impacts associated with the project were evaluated. The following mitigation measures will be implemented to reduce noise and ensure that Project noise impacts are less than significant.

- Locate noisy machines away from main areas of activity. Otherwise, screen plant from work areas by using noise 
screens, berms or material stacked to form barriers [12].

- $\quad$ Fit silencers to combustion engines. Ensure they are in good condition and work effectively [13].

- Maintain machines regularly - they will be quieter

Figure.3. Graphical analysis of noise level at different locations in exhibition hall

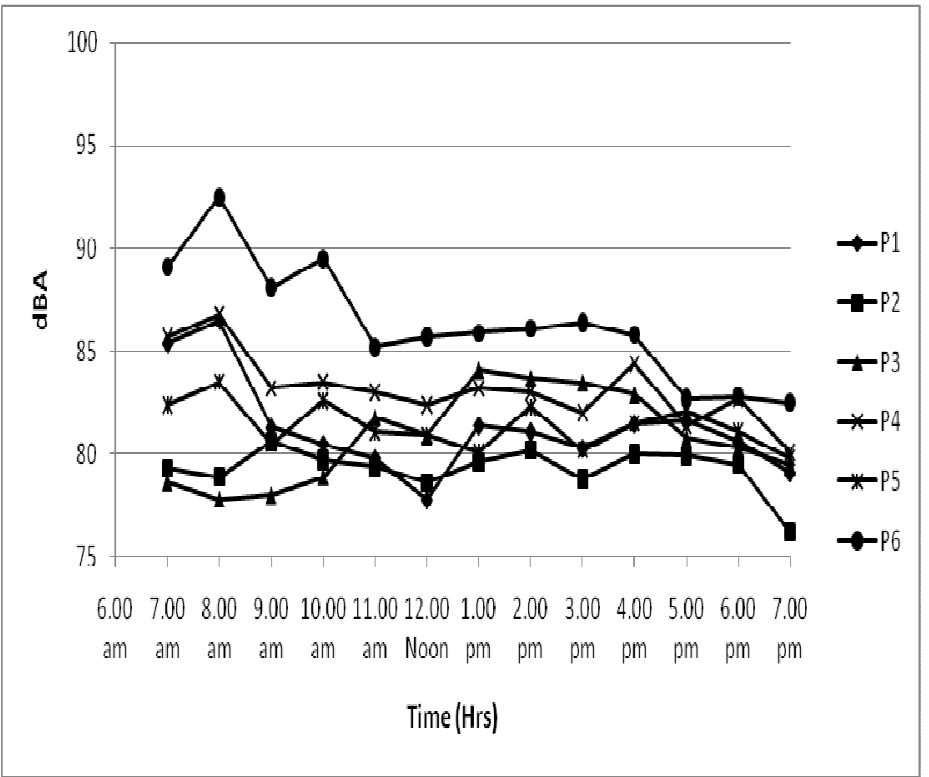

- Keep machinery covers and panels closed and well fitted. Bolts/fasteners done up tightly avoid rattles

- $\quad$ During both construction and operation, post warning signs in high noise areas and implement hearing protection program for work areas where noise levels exceed $85 \mathrm{dBA}$ [15].

Incorporate into the final design/procurement of Project facilities and equipment noise attenuation measures that ensure compliance with the legal requirements.

Table V Overall Noise Levels at Study Points Surveyed

\begin{tabular}{|c|c|c|c|c|c|}
\hline \multirow{2}{*}{ Point } & \multicolumn{5}{|c}{ Noise Levels, dBA } \\
\cline { 2 - 6 } & Minimum & Maximum & Mean & $\begin{array}{l}\text { Standard } \\
\text { Deviation }\end{array}$ & Variance \\
\hline P1 & 79.1 & 86.5 & 81.3 & 2.33 & 5.45 \\
\hline P2 & 76.2 & 80.6 & 79.28 & 1.08 & 1.17 \\
\hline P3 & 77.8 & 84.1 & 80.83 & 2.22 & 4.93 \\
\hline P4 & 80.1 & 86.8 & 83.18 & 1.73 & 2.99 \\
\hline P5 & 79.8 & 83.5 & 81.39 & 1.12 & 1.25 \\
\hline P6 & 82.5 & 92.5 & 86.33 & 2.90 & 8.45 \\
\hline
\end{tabular}

\section{Conclusion}

Noise was measured at various distances from the generator equipment. In this site the workers are working without any ear protection at a distance of about $2 \mathrm{~m}$ from the generators and are exposed to a minimum noise of $100 \mathrm{dBA}$ around $360 \mathrm{KVA}$ generators and 101.3dBA around 500 KVA generators. The study shows the permissible level of noise $(90 \mathrm{dBA})$ is reached at $7.0 \mathrm{~m}$ for $\mathrm{G} 1$ and $10.5 \mathrm{~m}$ for $\mathrm{G} 2$ generators. Noise from generators can be controlled by an increase in distance between the Generator and the worker or to introduce noise reduction screens or provide acoustic shield around.

So a hard barricading is needed at a minimum distance of $7 \mathrm{~m}$ and this distance is further increased to $10.5 \mathrm{~m}$ for $500 \mathrm{KVA}$ generators, which provides protection and minimizes the workers exposure in noisy zone.

An overall mean equivalent noise level of $82.05 \mathrm{dBA}$ was observed at 6 locations (78 measurements) in exhibition hall, which exceeds the threshold of $70 \mathrm{dBA}$ that represents a cautionary risk of hearing damage of construction workers of about 400 involved in this work area. The exposure ranged from a minimum of $76.2 \mathrm{dBA}$ to a maximum of $92.5 \mathrm{dBA}$.

This scenario might exists in any construction site wherever open generators are used for power generation. Hence during construction phase of any site needs to, investigate, document, evaluate, and attempt to take all feasible measures to reduce the noise at the source and implement hearing protection program for work areas where noise levels exceed $85 \mathrm{dBA}$.

\section{References}

1. Eaton S., "Noise \& Vibration in Work safe Industries", WCB of BC Engineering Report WCB-99006, 1999:25- 31.

2. Bares L.F., Salyers E.F., "A New Material Systems Approach for Controlling Heavy Equip. Operator Noise Exposure", 1980: 80-84.

3. Suggs C.W. "Noise Problems of Hand and Power Tools", Noise-con 81, 1981:339-342.

4. Singh, P., Noise pollution. Every Man's Science., 25 (1\&2), 1984: 231-235

5. Ringen, K. and Seegal, J. Safety and health in the construction industry. Annual Review of Public Health,1995:165-188.

http://dx.doi.org/10.1146/annurev.pu.16.050195.001121 (PMid:7639869)

6. The Columbia Encyclopaedia, Sixth Edition. Columbia University Press, 2008:105-133.

7. NIOSH, National Occupational Exposure Survey (19811983). Cincinnati, Ohio 1998:17-23.

8. Sinclair, J.D.N., And W.O. Haflidson: Construction noise in Ontario. Appl. Occup. Environ. Hygene 1995:457-460.

9. Greenspan, C.A., R. Moure-Eraso, D.H. Wegman, and L.C. Oliver: Occupational hygiene characterization of a highway construction project: A pilot study. Appl. Occup. Environ. Hyg. 1995:50-58. http://dx.doi.org/10.1080/1047322X.1995.10387611

10. Neitzel, R., N. Seixas, M. Yost, and J. Camp: An assessment of occupational noise exposures in four construction trades. MS thesis, Department of Environmental Health, University of Washington, Seattle, 1998:49-57. 
11. Paul Klinge. Symposium on "Modeling and Simulation of multi technological machine systems", ESPOO 2000, 2000:17- 24.

12. Bartholomae, R.C., and R.P. Parker: Mining Machinery Noise Control Guidelines, U.S. Department of the interior 1983:29-42.

13. Toth, W.J.: Noise Abatement Techniques for Construction Equipment.1979: 45- 79.

14. Ingemansson, S.: Noise control: Principles and practice (Part 7). Noise/News Int, 1995:237-343.

15. Legris, M., and P. Poulin: Noise exposure profile among heavy equipment operators, associated labourers and crane operators. Am. Ind. Hyg. Assoc. J, 1998:774-778. http://dx.doi.org/10.1080/15428119891010947

16. OSHA, Occupational Noise Exposure, Safety and Health Regulations for Construction, 1926.52(d) (1, 2), 2002.

17. Anon., "Exposure of Construction Workers to Noise", Construction Ind. Research and Information Association, UK, 1984: 96-102.

18. Ontario Ministry of Labour: Regulations for Industrial Establishments (Reg.851). Toronto, Canada: Ministry of Labour, 1986:122-27. 